\title{
The Apperception Approach for Stimulating Student Learning Motivation
}

\author{
Lusiana Hasan Puteri ${ }^{1}$
}

'Institut Agama Islam Darussalam,
Martapura, South Borneo, Indonesia
Email: lusianahasanputeri@gmail.com

Licensed:

This work is licensed under a Creative Commons Attribution 4.o License.

Keywords:

Motivation

Apperception

Learning.

\begin{abstract}
Learning is a process for making changes to the thoughts, the knowledge and the behaviours that students acquire from a teacher. Various methods or ways in teaching and learning process should be experienced by teachers to ensure that the knowledge can be delivered effectively to the students so that the learning objectives will be successful. Students will be enthused by the learning process if they have motivation and passion in absorbing the knowledge. One approach to stimulate the student's learning motivation is apperception. The apperception is a psychological interpretation of the mind, which is merged with the observations and experiences that possessed by a person. The appropriate apperception procedure will make the student feel relaxed and passionate when a positive behaviour usually reflects according to the learning process. This method is believed as one strategy that creates the successful of the teaching-learning process.
\end{abstract}

\section{Introduction}

Knowledge is the provision of information from an educator (teacher) to the students to gain understanding, learning, and experience. Provision of knowledge delivered by the teacher is usually conducted in the school environment, especially in the classroom, called teaching-learning process. Therefore, the teacher should prepare an effective technique approach based on various sources (Lam, Cheng, \& Ma, 2009; Miller, 2003) to motivate the students and minimalised any impediments in the teaching progress (Wilhelm \& Smith, 2006). Moreover, learning is a process for making changes to the thoughts, the knowledge and the behaviours that students acquire from a teacher. Through the active learning process, the students are expected to be able to develop their potential, at this activity the teacher plays the leading role to start the active learning process (Weber, 1991).

Teachers are the individuals who are liable for providing education, mentoring the students, and developing the potential of the students. In the knowledge delivery, the teachers are able to use the particular teaching method or teaching material (Oser, 1992). Thus, the knowledge transfer can be effectively delivered in the learning process. Moreover, various methods or ways in teaching and learning process should be experienced by teachers to ensure that the knowledge can be delivered effectively to the students so that the learning objectives will be successful (Elliott \& Travers, 1996; Miller, 2003; Wilhelm \& Smith, 2006). The learning process will enthuse students if they have motivation and passion in absorbing the knowledge (Ahn, 2014; Gubi, Platton, \& Nelson, 2008; Linnenbrink \& Pintrich, 2002). Moreover, the teachers strive to motivate at the initial delivery of understanding of knowledge to the students up to the learning evaluation.

Students who always pay attention to the lesson or subject given, will not be a problem for teachers because the students are already successful in developing their self-motivation as known as intrinsic motivation (Ariani, 2017; Mizuno, Tanaka, Fukuda, Imai-Matsumura, \& Watanabe, 2011). That condition will ease the teachers when they deliver the lessons. However, one social cognitive model could not assume whether the students are motivated or not in learning (Linnenbrink \& Pintrich, 2002) then, the teacher should be aware for the student's condition at the initial stage of the learning process. If the students fail to show that they have intrinsic motivation in encouraging themselves, then the teacher should provide the extrinsic motivation. This extrinsic motivation comes from outside of the students (Ariani, 2017) this may expectedly occur at the time of apperception transfer.

\subsection{Apperception Approach}

Apperception is a psychological interpretation of the mind, which is merged with the observations and experiences that possessed by a person (Bellucci, 2015; Danziger, 1980). In education, the apperception can be utilised as a "stepping stone". Before the teaching process begins, in order to be able to present a new lesson, the teacher should create a logical representation by relating the new lesson material with the previous material that is already understood by the students (Schor, 1998). Apperception also knows as one of the 
psychic phenomenon (McMurry, 1893) and this can be experienced by a student when there is a new impression that entered in the consciousness and associated with the previous impression together in the processing to develop a broader impression. This apperception approach has the procedure that is connecting the previous lessons with the new lessons as an association for the students to remind them to the previous lesson so it will be easier for the students to absorb the new lessons. The apperception functioned as the bridge to bring the student's perspectives into the educators'. This method is associating what has been known or experienced to what will be learned. Therefore, the perception is to receive new responses with the assistance of the real responses. In this process, the function of apperception itself is to create active learning in the initial stage to ensure that the students are ready to follow the learning activities. Also, the apperception is implemented to generate the student's motivation and attention in learning involvement. Furthermore, the apperception is essential since it focuses on the understanding, knowledge gaining, and ability improvement of the students (Brdar, Rijavec, \& Loncaric, 2006).

Apperception aims to form an understanding, while the teacher delivers the new material, it needs to be linked to the objects that the student has proficient at or it needs to relate it to the previous student's experience to facilitate them with comprehensive understanding (Knowles, 1999). The first alternative, at the beginning of the lesson the teacher should review the extent material which previously was learned and understood by the student through asking some questions or summarising the previous lesson. Secondly, the teacher could compare the new knowledge that will be presented with the previous lesson to create the connection between the materials. However, this approach is valid only when the new material is closely related to the previous material that already is understood by the students. The last option, the teacher could explain the concept comprehensively. This approach will be essential when the material is an entirely new lesson. When the students successfully develops the apperception, the students will be able to make an association between the previous lessons with the new lesson material, therefore it will make them easier to get involved for the next stage. The purpose of apperception is to raise the students' interest in learning so that the students will continuously feel motivated to learn. In delivering this apperception, the teacher needs to decide the proper method to ensure the student has the learning motivation (Schor, 1998; Williams \& Stockdale, 2004).

\subsection{The Teacher's Role}

The teachers are professional educators with the primary task of educating, teaching, guiding, directing, training, assessing, and evaluating the learners (Van Driel, Beijaard, \& Verloop, 2001) in early childhood education, formal education, primary education and secondary education. Beforehand, the teacher acted as a transmitter of teaching materials, knowledge transfer, skill alteration, and was the only source of learning. However, currently, the teachers have changed their role becoming mentor, coach, teacher, and facilitator. In addition to having responsibility and essential role in the community service, the teacher should be able to teach and manage involve the related administration at schools. Therefore the prospective teacher as a member of the profession also participates actively in the community of education personnel. This community or other similar institution has a critical role to prepare the professional teacher candidates through special assessment for the purpose of effective teaching and learning process. Every professional teacher is obliged to meet the requirements as a facilitator who is responsible individually in the field of education and the community (Black \& Wiliam, 1990).

\subsection{Learning Motivation}

Motivation is a transformation of energy in the inside of a person characterised by the emergence of powerful feeling and reaction to achieve the goal (Morgan, Harmon, \& Maslin-Cole, 1990). Further, motivation is a psychological condition that drives a person to do something. Thus, the motivation to learn is the psychological condition that drives a person to crave the knowledge (Jonassen \& Land, 2012; Stipek, 2002). Also, the understanding of learning motivation can be recognized as a general and a specific-situation state. As a general statement, learning motivation is a permanent character that encourages a person to conquer knowledge and skills in a learning activity. As a specific-situation state, learning motivation arises because the involvement of individuals in a particular activity is directed by the purpose of acquiring knowledge or mastering the skills being taught.

There are some theories about motivation: theory of needs, humanistic theory, and behavioural theory (Pink, 2011). Theory of needs states that an individual as a human being will not only be met one needs (Wahba \& Bridwell, 1976) but only will be satisfied if all needs are contented. Although all needs are met, a human being will unceasingly pursue another need. For these needs to be fulfilled, then the person will be motivated to do a specific action to achieve what is being desired. However, the satisfaction of the need fulfilment is often temporary since an individual always desires of something better. While humanistic theory believes that there is only one motivation that is coming from each. The motivation is owned by that individual all the time and wherever the individual present (Drucker, 2012). Thus, it is essential to respect or appreciate a human being who has the learning desire. Meanwhile, the behavioristic theory argues that the environment influences motivation (Jonassen \& Land, 2012). A motivated behaviour occurs when the 
consequences of that behaviour can thrill the individual's emotions, that is to be like or dislike. If the consequences of behaviour cause a sense of love, then the behaviour becomes stronger, but if the behaviour causes uncomfortable emotion, then it will be abandoned.

In fact, the motivation is the drive to perform a well-activity (Dahl, Heck, \& Smimou, 2011). The motivation to learn is the impetus to conduct learning activities with or without a vengeance (McCombs \& Whisler, 1997). The learning itself represent as a mental and physical activity that takes place in active interaction with the environment then resulting in changes, knowledge, understanding, skills, and values (Appelman, 2005; Dahl et al., 2011; Goldberg, 1994; Williams \& Stockdale, 2004). The changes are relatively constant. Thus the learning motivation involves particular activity, movement, and direction of the attitudes and behaviour of individuals to learn. Moreover, learning is a process marked by the changes that exist within an individual; this usually results in various forms, such as changes in knowledge, attitude, and behaviour. Supported by Gubi et al. (2008) the importance of student learning motivation that learning activities must be stimulated in various ways so that the desire in learning is stimulated on the interests within the students. According to Schor (1998) learning is a process that occurs in the human brain. The nerves and brain cells work to collect all that is captured by the eyes, heard by the ears, and then composed by the brain as a result of learning. That is the reason why people cannot learn if the brain function is impaired.

\subsection{Constructing the Apperception on Student's Learning Motivation}

In the process of teaching and learning the most important role is on the teacher (Bomia et al., 1997). The teacher's role, in this case, is a particular behavioural pattern formed as a typical characteristic of all officers of a particular job or occupation. Teachers should be responsible for the results of student learning activities through the interaction of teaching and learning (Bomia et al., 1997; Knowles, 1999; Williams \& Stockdale, 2004). Teachers are the leading factors that influence the success or failure of the learning process. Therefore the teacher must master the principles of learning in addition to inhibiting the material to be delivered. In other words, the teacher must be capable of creating a condition of learning as well as possible.

Initially, when the students enter the classroom, they brought different emotional conditions, some positive emotions while the others feel displeasure. Every condition will affect the learning process which impacts the process and the outcomes (Moore, 2015). Favourable learning conditions will positively affect the whole process of knowledge transfer, and vice versa. Although, this condition's effectiveness often influenced by the students' background -family, negative or positive experience, memories, and personal desire- which reflected in positive or negative outcome from the students' behaviour (Brown, 2011; Johnson, 2004; Maulana, Opdenakker, Stroet, \& Bosker, 2013; Ogden, 2008; Sofia, Todorova, Suárez-Orozco, \& Suárez-Orozco, 2008). According to Byrnes (1996) learning conditions associated with a learning situation that produces the outcome in the form of a behaviour improvement to an individual after being placed in the particular situation (Appelman, 2005).

Teachers should know how to deliver the knowledge with an appropriate way to their students (Williams \& Stockdale, 2004). When in the classroom, a teacher takes control of the activities to be undertaken while delivering the lesson to the students. If the student's response positively and express his/her enthusiasm for learning, then it is inevitable that the teacher utilises an effective teaching method (Goldberg, 1994; Knowles, 1999) In some cases, the teachers still prefer the conventional teaching method where it will be a one-way system where the teacher more active than the students who listen. However, students are required to be more active and proactive. Thus the teachers should improve their method to meet this different approach.

A monotonous learning environment can dampen students' desire in learning especially when they are less actively invited to participate in teaching and learning process (Moore, 2015). To overcome this, teachers need to prepare various approaches so that students do not lose the spirit of learning. The learning spirit of the student is influenced by various factors where their existence is significantly influenced their learning motivation (Olguin, 2017).

Teachers are not only required to be capable as the agent of learning, but they are also essential to be able to play the role of the agent of change for the students. Therefore, a teacher is expected to become an educator whose the role is not only limited to teaching but also be able to motivate their students. Based on the various definition of learning motivations is a driver for the students' action, to encourage them in a learning process involvement. The motivation also concerns why a student does so and what is the purpose to make him/her willing to do learning activities.

\subsection{The Procedure of Apperception for Learning Motivation}

There are two types of motivation, intrinsic motivation and extrinsic motivation. Intrinsic motivation arises as a form of awareness building from the student himself (Cantley, 2005). Usually, this type of motivation will be long-lasting as long as the goal has not been achieved. While the motivation from the outside (extrinsic) appears when there is inducement from the outside of the student to do what is desired by the lead (Ryan \& Deci, 2000). Typically, this extrinsic motivation does not last long, if the feedbacks still positive, then the learning activity will be still running. However, the teacher not always be able to make sure that the student continues to listen and absorb the lesson delivered during the learning and teaching activities. 
Since the teacher is a factor that affects the success or failure of the learning process, therefore, when the teacher is delivering the lesson, he/she needs the full attention of the students. When the learning conditions support student attention, the process and learning outcomes should run well. Notably, the attention of the students will influence their learning motivation. The primary concern is on how to built motivation in student's learning process. Consequently, the teacher expertise to stimulate the student's motivation is necessarily required.

Concerning on the teaching and learning process, the teacher will face the uncertainty of the students' condition in receiving the lessons (Brown \& Campione, 1986; Maulana et al., 2013). It can be identified when the teachers give apperception procedure in the form of relevant questions related to the teaching material delivered. This method occurs since the teachers need a variety of efforts in motivating the students to be well prepared in understanding the lesson. One of approach is giving the apperception to the students before the learning process takes place.

Giving the apperception at every start of the lesson is essential to ensure that the student is ready in absorbing the learning knowledge (Howard, 2002). Apperception can help the students to be steady in absorbing the lessons that have been transferred. Delivering apperception is a specialised skill that needs to be learned by the teacher because when the teachers enter the classroom for the first time will be a decisive moment for the next stages (Sugahara, Sugao, Dellaportas, \& Masaoka, 2016). The activities of apperception is an activity undertaken by the teacher to create a mentally prepared atmosphere that attracts the student's attention to be focused on things to be learned. Apperception is not only conducted at the beginning of the lesson but also at the beginning of each break from the core lesson given during the learning session. To attract the attention and to motivate the students for participating in the lesson, the teachers should lead to attempts with various approaches through raising curiosity or showing the enthusiastic behaviour of the students (Richardson, 1996). Motivated and caring students will show their passion, high spirit, and quick response to every teacher's lesson.

The first minute of the learning process is the vital time that determines the next learning condition (Brew \& Boud, 1995). For one hour of learning, the first minutes should be allocated for the apperception delivery process. The apperception process is conducted at the beginning of the learning process to influence the student's mentally prepared to learn. The appropriate apperception procedure will make the student feel relaxed and passionate that is usually reflected by a happy face, positive attitude, smile, and another relevant positive behaviour.

An appropriate apperception should be able to bring a cognitive conflict (Thiel, 1996) in this case, especially to the students. This conflict of cognition will be utilised in the learning process. By exploiting this conflicts of cognition, the curiosity feeling will arise within the student in learning for the material that is studied. Therefore the interest and motivation of the student to get involved in the learning process will be increasing. In the apperception process, the teachers should relate to what they have predicted to exist already in the student that related to the material will be given such as the knowledge of the previous material, prerequisites, informal knowledge, and perhaps student's experience at home. If the apperception has been developed in such a way by the teacher and successfully attract the attention of the students, then the learning motivation will start to grow within the students.

\section{Conclusions}

Regarding the teaching and learning process, the teachers need various efforts to motivate students to be ready to receive the lesson material (Wilhelm \& Smith, 2006). One approach that teacher allow to proceed is delivering the apperception procedure on students before the learning activity is commenced (Richardson, 1996). Giving the apperception at every start of the lesson is very prompting for assuring the readiness of the student in a learning activity. The apperception is able to support the students to be steady in absorbing the lessons that have been transferred. The apperception procedure requires a particular skill that needs to be learned by the teacher since this approach is a decisive moment starting from the teachers enter the classroom until the teaching and learning activity is finished.

Apperception process is an activity undertaken by the teacher to create a mentally prepared atmosphere that intended to stimulate the student's attention to be focused on things to be studied (Howard, 2002). The apperception is not only proceeded at the beginning of the lesson but also at every new material within the learning process in order to attract the student's attention and stimulate the student's motivation to keep continue the focus on the lesson. The apperception allows the teachers to raise the student's curiosity by showing the enthusiastic attitudes while initiating the lesson. This approach will be effectively motivated the students and stimulate their passion to be involved in lesson feedback and response to the teacher's instruction.

In the apperception procedure, the teacher connects every moment that the teacher predicts based on the student's capacity. This connection will involve every relevant source of the student that commonly will include the student's knowledge, the prerequisites, the informal knowledge, and the student's life experience, especially those who are significantly related with the lesson material that being studied. If the teacher has 
successfully created this apperception procedure, the learning motivation will grow and ease the student's to absorb every lesson delivered.

The apperception procedure as much as possible should contain contextual meaning starting from investigating the experience and capability of the students. Moreover, this approach should assure that the students will involve in the opening learning activities. After the students show their positive attention in learning, then the teacher may begin the learning process straight to the concept that essential for the teaching material.

\section{References}

Ahn, I. (2014). Relations between teachers' motivation and students' motivation a self-determination theory perspective. Purdue University, West Lafayette, Indiana.

Appelman, R. (2005). Designing experiential modes a key focus for immersive learning environments. Tech Trends, 49(3), 64-74.

Ariani, D. W. (2017). Why am i burnout and engaged? The role of motivation and personality. Journal of Psychological and Educational Research, 25(2), 61-89.

Bellucci, F. (2015). Logic, psychology, and apperception: Charles S. Peirce and Johann F. Herbart. Journal of the History of Ideas, 76(1), 69-91.

Black, P., \& Wiliam, D. (1990). Inside the black box: Raising standards through classroom assessment: Department of Education and Professional Studies, King's College London.

Bomia, L., Beluzo, L., Demeester, D., Elander, K., Johnson, M., \& Sheldon, B. (1997). The impact of teaching strategies on intrinsic motivation. U.S: Department of Education.

Brdar, I., Rijavec, M., \& Loncaric, D. (2006). Goal orientations, coping with school failure and school achievement. European Journal of Psychology of Education, 21(1), 53-70.

Brew, A., \& Boud, D. (1995). Teaching and research: Establishing the vital link with learning. Higher Education, 29(3), 261273.

Brown, A. L., \& Campione, J. C. (1986). Psychological theory and the study of learning disabilities. American Psychologist, 41(10), 1059-1068.

Brown, T. D. (2011). An investigation of the relationship between parent involvement and student motivation. Capella University.

Byrnes, J. P. (1996). Cognitive development and learning in instructional contexts. Boston: Allyn and Bacon.

Cantley, C. (2005). Predicting academic intrinsic motivation the role of parents, teachers, and child factors. St. John's University, New York.

Dahl, D. W., Heck, J. L., \& Smimou, K. (2011). Does motivation matter? Managerial Finance, 37(7), 582-609. Available at: $10.1108 / 03074351111140243$.

Danziger, K. (1980). Wundt's theory of behavior and volition. In R.W. Rieber (Ed.), Wilhelm Wundt and the making of a scientific psychology (pp. 73-87). New York: Plenum Press.

Drucker, J. (2012). Humanistic theory and digital scholarship. In M.K Gold (Ed.), Debates in the Digital Humanities (pp. 85-95). Minneapolis: University of Minnesota Press.

Elliott, S. N., \& Travers, J. F. (1996). Educational psychology: Effective teaching, effective learning. Brown \& Benchmark Madison, WI

Goldberg, M. D. (1994). A developmental investigation of intrinsic motivation: Correlates, causes, and consequences in high ability students. University of Virginia.

Gubi, A., Platton, P., \& Nelson, A. (2008). Motivating students school psychologists as motivational change agents. National Association of School Psychologists, 37(4), 34-38.

Howard, J. (2002). Eliciting young children's perceptions of play, work and learning using the activity apperception story procedure. Early Child Development and Care, 172(5), 489-502.

Johnson, D. E. (2004). Kant's dog. Diacritics, 34(1), 18-39.

Jonassen, D., \& Land, S. (2012). Theoretical foundations of learning environments. New York: Routledge.

Knowles, K. T. (1999). The effect of teacher engagement on student motivation and achievement. University of Maryland.

Lam, S.-f., Cheng, R. W.-y., \& Ma, W. Y. K. (2009). Teacher and student intrinsic motivation in project-based learning. Instructional Science, 37(6), 565-578.

Linnenbrink, E. A., \& Pintrich, P. R. (2002). Motivation as an enabler for academic success. School Psychology Review, 31 (3), 313-327.

Maulana, R., Opdenakker, M. C., Stroet, K., \& Bosker, R. (2013). Changes in teachers' involvement versus rejection and links with academic motivation during the first year of secondary education: A multilevel growth curve analysis. Journal of Youth and Adolescence, 42(9), 1348-1371. Available at: 10.1007/s 10964-013-9921-9.

McCombs, B. L., \& Whisler, J. S. (1997). The learner-centered classroom and school: Strategies for increasing student motivation and achievement. San Fransisco, CA: The Jossey-Bass Education Series.

McMurry, C. A. (1893). The elements of general method based on the principles of Herbart. Bloomington, IL: Public School Publishing.

Miller, E. J. W. (2003). Teaching methods, the herbartian revolution and Douglas clay Ridgley at Illinois State Normal University. Journal of Geography, 102(3), 110-120.

Mizuno, K., Tanaka, M., Fukuda, S., Imai-Matsumura, K., \& Watanabe, Y. (2011). Relationship between cognitive function and prevalence of decrease in intrinsic academic motivation in adolescents. Behavioral and Brain Functions, 7(1), 44. Available at: 10.1186/1744-9081-7-4.

Moore, O. O. (2015). Motivating unmotivated students to focus on academics an action research study. Capella University.

Morgan, G. A., Harmon, R. J., \& Maslin-Cole, C. A. (1990). Mastery motivation: Definition and measurement. Early Education and Development, 1(5), 318-339. 
Ogden, W. R. (2008). And the beat goes on. Journal of Instructional Psychology, 35(1), 94-102.

Olguin, J. E. (2017). A correlational study on student retention student identity, intrinsic, extrinsic, and a motivation. University of Phoenix.

Oser, F. K. (1992). Effective and responsible teaching: A new synthesis. San Fransisco: Jossey-Bass.

Pink, D. H. (2011). Drive: The surprising truth about what motivates us. New York: Penguin.

Richardson, V. (1996). The role of attitudes and beliefs in learning to teach. In J. Sikula (Ed.), Handbook of Research on Teacher Education (pp. 102-119). New York: Macmillan.

Ryan, R. M., \& Deci, E. L. (2000). Intrinsic and extrinsic motivations: Classic definitions and new directions. Contemporary Educational Psychology, 25(1), 54-67.

Schor, L. I. (1998). Apperception as a primary process of the psyche: Implications for theory and practice. Auburn University.

Sofia, B., Todorova, I. L. G., Suárez-Orozco, C., \& Suárez-Orozco, M. (2008). Changing stories the evolving narratives of immigrant children. Cognition, Brain, Behavior. An Interdisciplinary Journal 12(4), 345-367.

Stipek, D. J. (2002). Motivation to learn: Integrating theory and practice (4th ed.). Boston: Allyn \& Bacon.

Sugahara, S., Sugao, H., Dellaportas, S., \& Masaoka, T. (2016). The effect of body-movement teaching, learning motivation and performance. Meditari Accountancy Research, 24(3), 414-437. Available at: 10.1 108/medar-02-2015-0006

Thiel, U. (1996). Between Wolff and Kant: Merian's theory of apperception. Journal of the History of Philosophy, 34(2), 213232.

Van Driel, J. H., Beijaard, D., \& Verloop, N. (2001). Professional development and reform in science education: The role of teachers' practical knowledge. Journal of Research in Science Teaching: The Official Journal of the National Association for Research in Science Teaching, 38(2), 137-158.

Wahba, M. A., \& Bridwell, L. G. (1976). Maslow reconsidered: A review of research on the need hierarchy theory. Organizational Behavior and Human Performance, 15(2), $212-240$.

Weber, R. N. (1991). The relationship between cooperating teachers' feedback styles and the intrinsic motivation of student teachers. Dissertation the College of William and Mary.

Wilhelm, J., \& Smith, M. W. (2006). What teachers need to know about motivation. Voices from the Middle, 13(4), 29-31.

Williams, R. L., \& Stockdale, S. L. (2004). Classroom motivation strategies for prospective teachers. Teacher Educator, 39(3), 212-230. 